\title{
To Be or To Be: The Dilemma of Copula Choice for Beginning-Level Learners of Spanish
}

\author{
SAMUEL FRANCIS \\ Colorado State University
}

Received: 10 October 2006 / Accepted: 29 October 2006

ISSN: 1697-7467

\begin{abstract}
English-speaking learners of Spanish encounter great difficulties in acquiring the uses of the verbs ser and estar. The present study presents some traditional analyses of these verbs. The researcher tested university students' understanding of the target forms via comprehension and production tests. Results of the investigation lend some empirical support to the claim that learners progress through identifiable stages in second language acquisition. Pedagogical implications are also discussed.

Key words: second language acquisition, pedagogy, ser and estar, stages of acquisition

RESUMEN: Los estudiantes de español angloparlantes encuentran grandes dificultades en adquirir los usos de los verbos ser y estar. En este estudio, se presentan algunos análisis de estos verbos. El investigador examinó a estudiantes universitarios en su comprensión de estas formas a través de exámenes en comprensión y producción. Los resultados de la investigación prestan apoyo empírico a la propuesta de que los estudiantes pasan por etapas identificables en la adquisición de una segunda lengua. El trabajo también presenta varias implicaciones pedagógicas para la didáctica de estos verbos.
\end{abstract}

Palabras claves: adquisición de lenguas, pedagogía, ser y estar, etapas de adquisición

\section{INTRODUCTION}

In learning Spanish as a second or foreign language, there are several grammatical structures that are infamous for the difficulty they cause English-speakers. Especially for beginning-level learners, understanding the sometimes subtle differences between the main Spanish copulas ser and estar, can be challenging and frustrating since both of these verbs may usually be translated to English 'to be'. While some of the distinctions between these two verbs may be categorized rather easily, other situations require more analysis by the speaker in order to determine which verb should be used. Even after years of formal instruction or natural exposure to Spanish, learners still have difficulties using these forms accurately. Research has attempted to identify how learners acquire an understanding of ser and estar and begin to use them proficiently with the aim to aid the natural acquisition processes. 


\section{The Linguistic Problem}

In addition to ser and estar, there are a number of Spanish verbs which may, depending on the context, be translated as English to be, including haber, hacer, tener, quedar, sentar, verse, salir, hallarse, encontrarse and resultar. Because the distribution of these verbs is primarily complimentary, the Spanish student may memorize the set of conditions in which each verb is used. That is to say, in many situations where the verb ser is required, estar may not be employed and vice versa. To this end, Bull (1965) recommends that students must first recognize and identify the cues that determine the selection of ser or estar, and then grasp the meaning of contrasting pairs. However, it has been estimated that approximately 80 percent of adjectives may be preceded by either ser or estar, depending on the context (Mesa Alonso et al. 1993).

\subsection{Description of the target form}

Many beginning-level textbooks present the target forms as follows.

Cases which require ser:

- Nationality or precedence; es boliviano, es de España

- Time-telling; son las cuatro

- Profession and affiliation; es abogada, es republicana

- Possession; es de George

- Physical make up; es de seda

- Passive constructions; es abierta

Cases which require estar:

- Progressive constructions; está comiendo

- Location; está en el auto

- Mental or physical states; está contento, está enfermo

According to the traditional approach, the key semantic distinction between these two copulas is one of permanent or inherent qualities requiring ser versus temporary or accidental ones for which estar is used. Bull (1965) sees the fundamental difference between ser and estar not as one of permanence versus temporariness, but as one of change versus no change. He emphasizes that only the speaker is qualified to make this classification and does so with reference to his or her own logic and previous experience. In the speaker's analysis, estar implies a change to the referent while ser is used to describe entities which the speaker views as having unchanging characteristics. A customer, expecting to pay a certain amount but finding a higher price would comment, está caro, 'it is expensive' (compared to the expected norm the speaker has in his or her mind).

Stockwell et al. (1965) agree that ser expresses the norm and situates the subject as a member of the class of subjects with some quality. The statement Ella es simpática, 'She is nice,' classifies the subject as a member of the class of 'nice (people)'. Estar, on the other hand, makes a comment about the subject without classifying it. Thus, Ella está simpática, She is (seems) nice, does not classify but rather expresses that the speaker views her as being nice. 
Bolinger (1991) takes the analysis one step further by classifying the subjects of the copula into one of three categories before applying the change versus no change criterion. Metaphysical entities such as God or love are classified as infinite and as such always require ser because this class of subject is comprised of 'pure concepts, nothing interferes with our attributing to them some quality as of their essence' (Bolinger 1991: 53).

Bolinger (1991) further observes that infinitesimal subjects are those which express events of such limited duration that they are incapable of undergoing a change. With these subjects, the first impression is the only one the speaker has available to make reference to. According to this theory, this class of subjects will also require ser, as in el casamiento fue bonito, 'the wedding was pretty'.

Either ser or estar may be used with Bolinger's class of evolutionary subjects; those are subjects which are not timeless or points in one's daily experience. These entities have more duration than the infinitesimal ones. This reasoning seems to be circular though, when Bollinger explains this category. 'It is here that estar enters in - practically by definition since only of things conceived as changing do we have attributes assumed to change' (Bolinger 1991:54). The choice of copula in these cases depends on the speaker's viewpoint and reasoning based on the change versus no change opposition.

Adjectives that Whitley (2002) calls affiliation and which have no real antonym or gradation on a scale, call for ser. These adjectives are like labels and although a change from one affiliation is possible one either possesses the quality or does not, with no middle ground. For example, the phrase soy mexicano, 'I am Mexican', is either true in its entirety or it is not and even after naturalizing, one would not then declare estoy americano.

Some linguists suggest that either the adjectives or the copulas themselves possess aspectual features (Gili Gaya 1973, Bosque 1992, Lema 1995). For example, adjectives lacking the perfective feature select ser. It could also be argued that the feature directionality is more accurate for copula selection. According to these analyses, copula selection is flexible because it is not determined solely by the adjective, but by the semantic value of the copula and the adjective together.

Similarly, Bosque (1992) and Lema (1995) suggest that it is the adjective in the predicate and not the copula that has an inherent perfective feature. Thus, adjectives such as despierto 'awake', lleno 'full', seco 'dry' or sucio 'dirty' have perfective qualities and therefore select estar. In contexts with ser, the perfective aspect goes unrealized. Adjectives lacking the perfective feature select ser. According to these analyses, copula selection is flexible because it is not determined soley by the adjective, but by the semantic value of the copula and the adjective together.

Pedagogically, the tendency still seems to be to summarize the sometimes elusive differences between ser and estar similarly to the explanation offered by Butt and Benjamin (1994: 375). They first state that the main difference is that 'ser denotes nature or identity while estar denotes condition, state or place.' Then follow lists of examples of each usage and finally the interchangeable cases and those which contrast in meaning, depending on the verb used.

\section{SeCONd language aCQuisition ReSEarch}

In second language acquisition research, VanPatten (1987:64) presented a developmental pattern through which learners of Spanish pass: 1) absence of copula in learner speech; 2) selection of ser to perform most copula functions; 3) appearance of estar with progressive; 
4) appearance of estar with locatives; and 5) appearance of estar with adjectives of condition. Learners progress in proficiency in the phases listed above regardless of the way or order in which a teacher presents them. VanPatten has been criticized for 'a lack of detail in the classification of the pre-adjectival contexts for copula selection' and for failing to identify the length of time learners omit copulas completely (Geeslin 2002:336).

Addressing this weakness, recent second language acquisition research in this area has focused on copula choice before adjectives, the position which causes greatest difficulty for learners. For example, some researchers have based their studies on theories of semantic classes for adjectives. Silva-Corvalán (1994) used the adjective classes listed in Table 1 to investigate a possible correlation between copula selection and adjective type.

Table 1. Categories of Adjective Classes (adapted from Silva-Corvalán, 1994:107).

\begin{tabular}{l|l}
\hline \multicolumn{1}{c|}{ Adjective Class } & \multicolumn{1}{c}{ Example } \\
\hline Age & Joven 'young' \\
\hline Size & Alto 'tall' \\
\hline Sensory character & Dulce 'sweet' \\
\hline Physical appearance (animate) & Curioso 'curious' \\
\hline Description (non-animate) & Liso 'smooth' \\
\hline Evaluation & Interesante 'interesting' \\
\hline Miscellaneous & Borracho, 'drunk' inocente 'innocent' \\
\hline Moral value & Honesto 'honest' \\
\hline Color & Amarillo 'yellow' \\
\hline Class & Pobre 'poor' \\
\hline
\end{tabular}

However, there has not been agreement about how to categorize adjectives. Certainly there is some overlap between categories and many adjectives may belong to more than one class, depending on the context. Table 2 shows the classes according to Geeslin (2000). These differences cast doubt on the results obtained in such analyses, as each researcher determines his or her own criteria for categorizing these adjectives.

Table 2. Categories of Adjective Classes (from Geeslin 2000)

\begin{tabular}{l|l}
\hline \multicolumn{1}{c|}{ Adjective Class } & \multicolumn{1}{c}{ Example } \\
\hline Physical state & Enfermo 'sick' \\
\hline Mental state & Enojado 'mad' \\
\hline Sensory characteristic & Frí 'cold' \\
\hline Age & Joven 'young' \\
\hline Size & Grande 'big' \\
\hline Physical appearance & Guapo 'handsome' \\
\hline Description of a person(ality) & Inteligente 'intelligent' \\
\hline Description/evaluation & Dificil 'difficult' \\
\hline Color & Azul 'blue' \\
\hline Class/status & Rico 'rich' \\
\hline
\end{tabular}


It is precisely due to the dependence of a context that the present study stepped away from attempting to classify adjectives and instead, examined copula selection in relation to the communicative attempt the speaker wished to achieve. This study then, is not limited to examining only adjectives in the predicate, but additionally NPs (as in

Ella es mi maestra favorita, 'She is my favorite teacher') and PPs (as in Los chicos están en la piscina, "The boys are in the swimming pool') and even when used to form the progressive (as in Soledad y Alejandra están hablando por teléfono 'Soledad and Alejandra are talking on the phone). This approach is hoped to better correspond to the way in which learners tackle the problem of copula selection.

The categories employed in the present study are outlined in Table 3. They roughly correspond to the traditional pedagogical classifications of the uses for ser and estar and were determined after considering in general terms the communicative goals speakers have when selecting copulas. It was hoped that this type of analysis would more accurately reflect the beginning-level learner's decision.

Table 3. Communicative Functions of Ser and Estar.

\begin{tabular}{|c|c|}
\hline SER & ESTAR \\
\hline $\begin{array}{l}\text { - Description - Natural Quality } \\
\text { El fútbol es interesante, 'Soccer is } \\
\text { interesting' }\end{array}$ & $\begin{array}{l}\text { Progressive Constructions } \\
\text { Gabriela estaba comiendo } \\
\text { cuando pasó el camion de } \\
\text { bomberos, 'Gabriela was eating } \\
\text { when the fire truck went by' }\end{array}$ \\
\hline $\begin{array}{l}\text { - Physical Make-up } \\
\text { Son de oro puro, 'They are (made } \\
\text { of) pure gold' }\end{array}$ & $\begin{array}{l}\text { Description - Conditions or } \\
\text { Resultant States } \\
\text { Fito está triste, 'Fito is sad' } \\
\text { Quisieron salir pero la puerta } \\
\text { estaba cerrada, 'They wanted to } \\
\text { leave but the door was closed' }\end{array}$ \\
\hline $\begin{array}{l}\text { - Affiliation / Identification } \\
\text { Gloria es modelo, 'Gloria is a } \\
\text { model' }\end{array}$ & $\begin{array}{l}\text { Locating an Entity } \\
\text { Los mariscos están en la mesa, } \\
\text { 'The seafood is on the table' }\end{array}$ \\
\hline $\begin{array}{l}\text { - Origin } \\
\text { Somos de San Diego }\end{array}$ & $\begin{array}{l}\text { Description - Change from the } \\
\text { Norm } \\
\text { Rosa, iqué elegante estás!, 'Rosa, } \\
\text { you are (look, seem, etc.) so } \\
\text { elegant! }\end{array}$ \\
\hline $\begin{array}{l}\text { - Time-telling } \\
\text { Son las tres, 'It is three o'clock' }\end{array}$ & \\
\hline
\end{tabular}

Looking at the categories for ser, we first see that of Description of a Natural Quality. This category is intended to include those instances in which the adjective is seen as being a natural or inherent quality of the referent and no further judgment is being made by the 
speaker about that quality or referent; El fútbol es interesante, 'Soccer is interesting'. The category of Physical Make-up includes all statements that describe the material of which the referent is made; Son de oro puro, 'they are (made of) pure gold'. The category of Affiliation or Identification describes those statements in which the speaker is identifying the referent as a member of a given class, which, although it may change over time, may either possess that quality or not at any given point; Gloria es modelo, 'Gloria is a model'. In this category are included statements of possession as well;'Esta bicicleta es de Jorge, This is Jorge's bicycle. The category of Origin comprises all statements which identify the origin of the referent;'Somos de San Diego, We are from San Diego. Finally, sentences in which the speaker states or asks for the time of day are included in the category of Time-telling, 'Son las tres, 'It is three o'clock'.

On the other hand, this analysis separated the uses of estar into four main communicative roles. First was to describe events in progress in which a form of the progressive is required; Gabriela estaba comiendo cuando pasó el camión de bomberos, 'Gabriela was eating when the fire truck went by'. Next, sentences which describe physical, emotional or mental states of their subjects are categorized as Description - Conditions or Resultant States; Fito está triste, 'Fito is sad'. Included in this category are also those sentences in which the condition of the subject is viewed as being the result of some event or action; Quisieron salir pero la puerta estaba cerrada, 'They wanted to leave but the door was closed'. For sentences which locate an entity in space the category Location of an Entity was used; Los mariscos están en la mesa, 'The seafood is on the table'. Finally, all sentences which describe a change from the normal attributes or characteristics of the referent form the category of Description Change from the Norm; Rosa, iqué elegante estás!, 'Rosa, you are (look, seem, etc.) so elegant!' This last category is one which may require significant context in order to establish a norm and then determine that the subject is being depicted as something other than how it would be expected. In the example, Rosa, who is normally quite casual in her appearance, is not being identified as a member of the class of elegant people, but rather as possessing temporarily the qualities of that class.

Not all the uses or communicative functions of ser and estar are included in the list simply because the subjects who participated in the study had not been exposed to them. One notable exception is the use of ser to form the passive.

\section{The STUdY}

\subsection{Data collection procedures}

Data were collected via a test in which subjects completed several linguistic tasks designed to evaluate their proficiency in both production and reception. Testing areas included grammaticality judgment involving the target forms, guided production of the forms and finally a short descriptive essay.

The first section of the test was an error identification task. Each sentence had four different words or phrases underlined, which were lettered A, B, C, and D. Subjects were told that the sentences may contain an error in grammar. Their task was to identify the underlined section containing the error. If the subject did not find any error in the sentence, he or she 
was to mark letter $\mathrm{E}$ on the answer sheet, indicating that the sentence was grammatically correct. Examples 1 through 4 show some of the types of sentences that made up this part of the test.

(1) ¿Saben ustedes dónde es el dinero para mis libros nuevos?
A B
$\mathrm{C}$
$\mathrm{D}$

(2) Bárbara es buscando un novio rico y guapo con pelo negro y un Mercedes.
A B
C D

(3) Mi amigo puede ver todos los partidos de fútbol gratis porque está policía.
A B
$\mathrm{C}$
$\mathrm{D}$

(4) Muchas de las personas en mi apartamento están de Chile.
A B
$\mathrm{C}$
$\mathrm{D}$

The test was composed of:

- 40 incorrect sentences using ser; (eight tokens from each of the five categories)

- 40 incorrect sentences using estar; (ten from each of the four categories)

- 20 distracter sentences with grammatical errors unrelated to the ser / estar distinction (Examples include, the incorrect choice of prepositions, lack of gender agreement between nouns and adjectives, and lack of agreement between subjects and verbs for person and/or number)

The second section of the test involved guided production of the target forms. The subjects read three short texts in English (average length 678 words). After each one, they answered ten questions which elicited the use of either ser or estar. Although the questions were written in English, the subjects were instructed to answer using complete sentences in Spanish. The texts and the questions were in English in order to avoid giving the subjects any clues about which verb should be used.

The third test section was a picture description task. Subjects saw a picture and were asked to describe it in Spanish. Again, they were prompted to include in their descriptions information which would require the use of the target forms such as physical descriptions, locations, feelings and actions in progress. Pictures included scenes from a classroom, a restaurant, and a party. In each case, a number of people were pictured engaged in various activities. Subjects were asked to describe the scenes, including where it was, what the different people were doing, and what the people were like.

Tests were scored according to the number of correct responses given. In the first section, there was a possible total of 80 points since there were 80 items containing the target forms and each one had a value of one point. Participants earned a point for accurately identifying an erroneous use of the target forms or for each correct production of the target forms. In the sentence production sections of the test, subjects earned a point for each correct use of the target forms. Scores were calculated for each of the categories of ser and estar 


\subsection{Results and Analysis}

The data obtained from the tests were calculated and plotted on charts both by task type and by communicative function for each of the target forms. Figure 1 shows the total percentages of correct uses of the target forms. For the verb estar, we see a steady level of proficiency with little variation from task to task. In the error identification section, these participants spotted $58.86 \%$ of the erroneous uses. They were able to use estar correctly in their own production $57.09 \%$ of the time. For ser however, these subjects produced grammatical sentences in $81.03 \%$ of their attempts but could identify ungrammatical uses only $70.98 \%$ of the time. Still, the accuracy with ser in both tasks was much greater than for estar. Subjects' scores in the error identification portion of the test were $12 \%$ better when dealing with ser than with estar. In the production portion, subjects' scores were $24 \%$ higher when using ser than when using estar.

In Figure 2 we see the percentages at which the participants accurately used the copula ser or identified errors with its use for each of the communicative functions employed in the study. It is interesting to note that subjects were more accurate in their own production than in the grammaticality judgment task in all of the communicative functions.

Figure 1. Totals - Ser and Estar by Task.

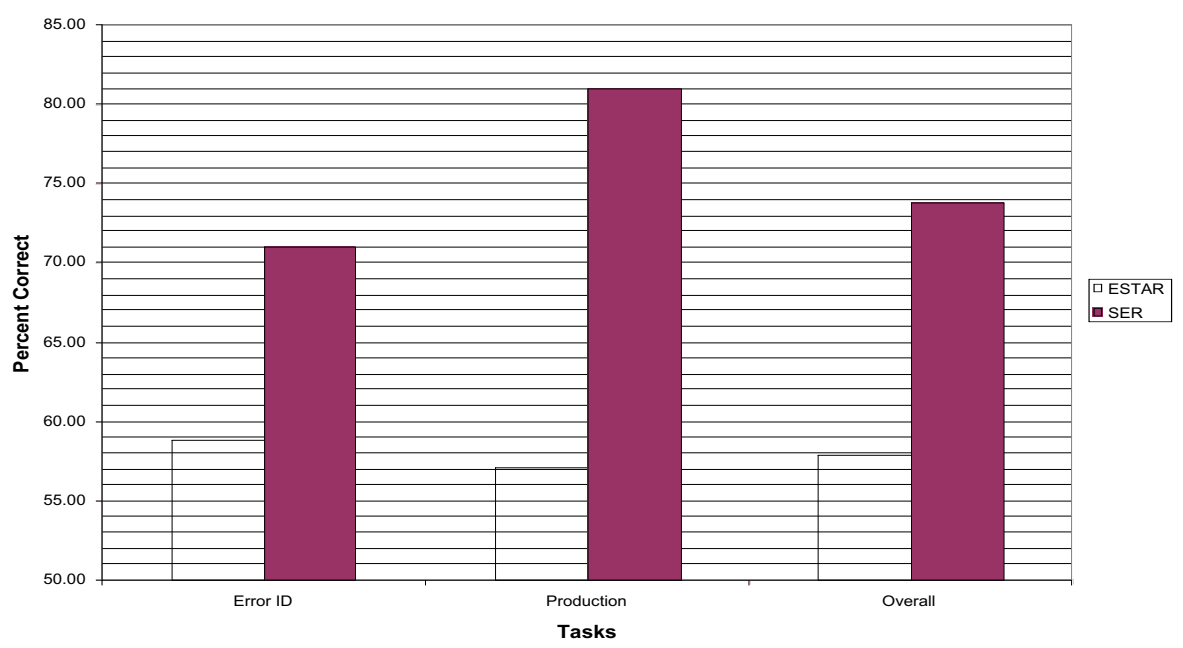


Figure 2. Ser - by Communicative Function.

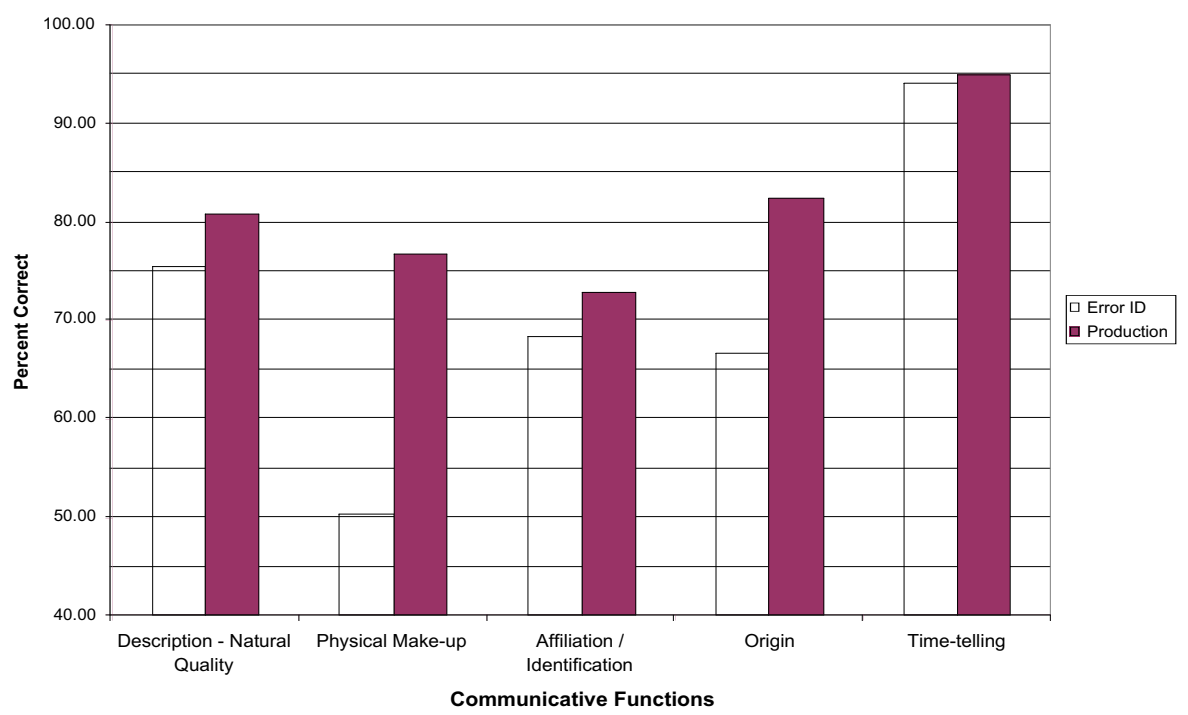

Figure 3 averages together the tasks of error identification and production to give an overall look at the participants' proficiency in the verb ser. They were most proficient at telling time, second at stating the referent's origin, next at describing the natural or inherent qualities of the subject, fourth at stating the physical make-up of the subject and they were least proficient at stating the subject's affiliation.

Figure 3. Ser - Overall Error Identification and Production.

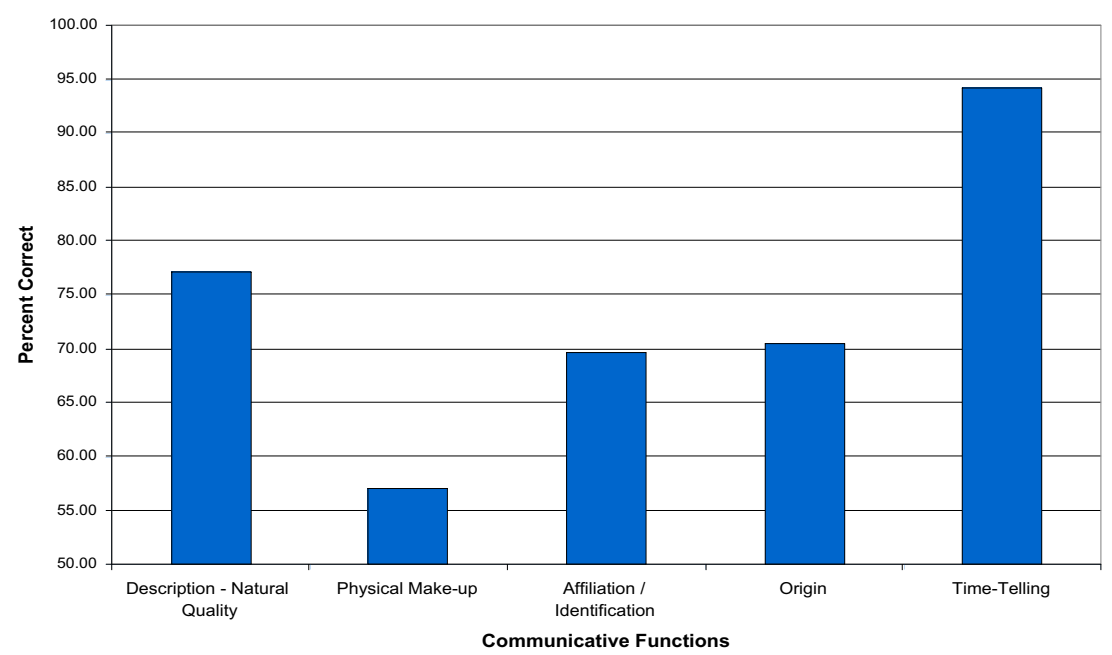


In Figure 4 we see the percentages at which the participants accurately used the copula estar or identified errors with its use for each of the communicative functions employed in the study. Unlike what we observed with ser, here the subjects were better at using estar only for the functions of locating an entity and forming the progressive. For the functions of describing conditions or changes from the norm, the participants could identify errors on average $13 \%$ better than what they could use estar correctly in their own productions.

Figure 4. Estar by Communicative Function.

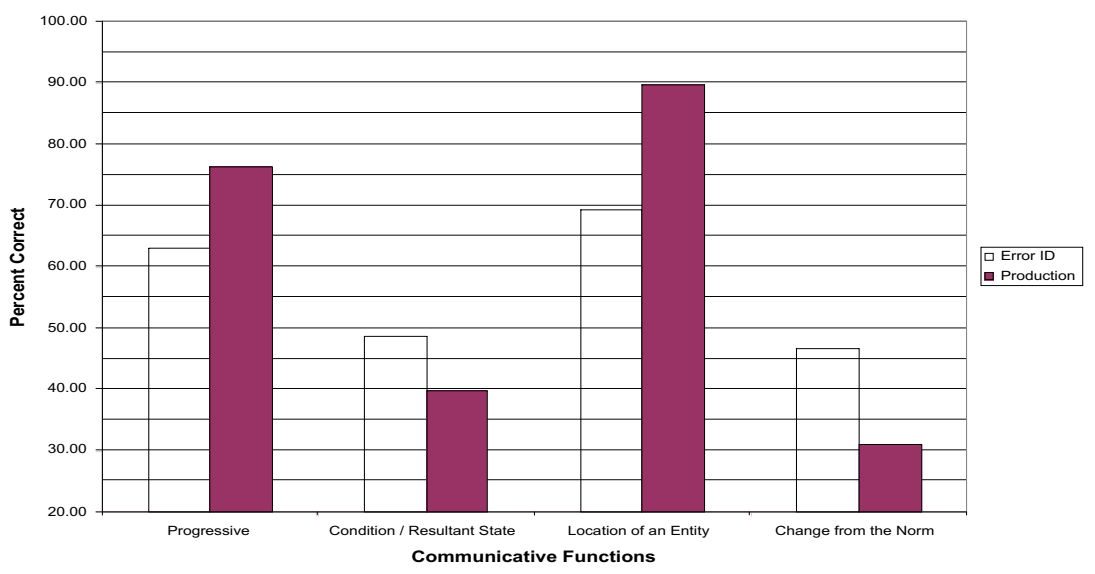

Figure 5 averages together the tasks of error identification and production to give an overall look at the participants' proficiency in the verb estar. Subjects were most proficient at locating an entity and next at forming the progressive. Dropping $21.8 \%$, their third best category for estar was that of describing conditions and resultant states. Lastly was describing changes from the norm.

Figure 5. Estar - Overall Error Identification and Production.

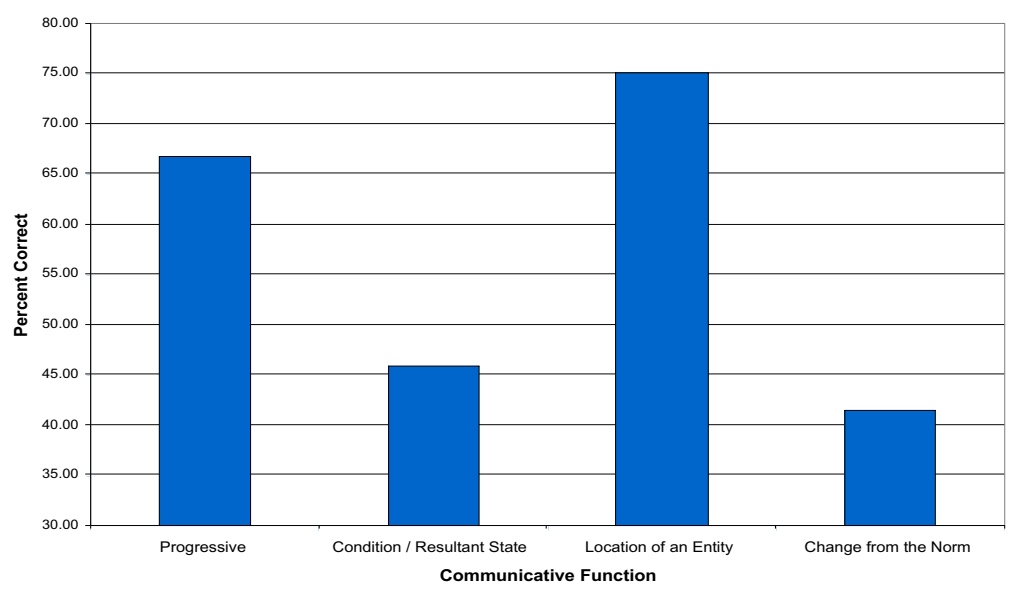




\section{Discussion}

Perhaps the most obvious finding in the present study is the vast difference in proficiency when comparing ser with estar. Overall, we observed the subjects score $15.8 \%$ higher when dealing with the verb ser. This difference was greatest, at $23.94 \%$, when we focused on the production tasks. These differences can most likely be attributed to two factors.

First, as we observe the overall scores, those from ser are consistently higher than those from estar. The developmental pattern proposed by VanPatten (1987) and later echoed by researchers such as Geeslin $(2000,2002)$ and Ramírez-Gelpi (1995) predicts that beginninglevel learners first gain proficiency with ser.

Second, looking at the difference in scores for the production tasks, recall that participants received a point for each correct use of the target forms. If ser was used where the context called for estar, no point was given and vice versa. The second stage of development is to use ser for most functions. Thus, when these subjects faced a decision as to which verb to use, they may have guessed ser in the majority of the instances. This way, for the cases requiring ser, their scores were quite high. For cases requiring estar their scores were quite lower.

The third stage as proposed by VanPatten is that learners begin to replace the erroneous ser with estar to locate entities. This too was supported by the data as we see that, among the communicative functions for estar, the subjects scored highest in the category of locating an entity, doing so almost $90 \%$ of the time in their productions.

These learners also seem to be associating estar with progressive constructions. In $76 \%$ of their productions, these subjects accurately chose estar to form the progressive. Compared to the less than $50 \%$ accuracy for describing conditions, resultant states or changes from the norm, it appears that a developmental pattern does indeed exist.

This study can offer more specific indications than were previously available when looking at the communicative functions of the copulas. By categorizing the functions of ser and estar we can see that while the overall pattern fits that suggested by VanPatten, a finegrained analysis reveals that these subjects did not demonstrate a preference for ser in every situation. Specifically when asked to identify the errors in the category of Physical Make-up, the participants were able to do so only $50.34 \%$ of the time, thereby judging as grammatical half of the sentences constructed with estar for this function such as *Las casas están de madera importada, 'The houses are (made of) imported wood'.

Therefore, although beginning-level learners may apparently be favoring ser indiscriminately for most copula functions, it seems that as they progress in proficiency, this does not hold true. So, just as the initial stage of copula emission is replaced by use of ser almost everywhere, this stage is in turn replaced by more target-like use of the copulas according to their communicative function. At least for these learners, the functions of time-telling and identifying the origin of the subject are equated with ser while they are still testing hypotheses regarding the proper copula to fulfill the functions of describing the physical make-up or the affiliation of the subject.

When considered together with the findings from previous research, the data from the present study suggest the following 11 developmental stages in the acquisition of ser and estar: 
1) Omission of copulas

2) Use of ser for most communicative functions requiring a copula

3) Discriminate use of ser to tell time

4) Correctly replacing ser with estar for locating entities

5) Correctly replacing ser with estar for forming progressive

6) Discriminate use of ser for describing a referent's natural or inherent qualities

7) Discriminate use of ser for stating origin

8) Discriminate use of ser for identifying a subject or describing a referent's affiliation

9) Discriminate use of ser for describing a referent's physical make-up

10) Use of estar for conditions and resultant states

11) Use of estar for describing a change from the norm

\subsection{Pedagogical Implications}

The consistent findings in studies on developmental patterns in SLA are that learners will not acquire a grammatical form out of its order in the developmental sequence, despite different instructional conditions or techniques. Instruction may only speed up the rate of acquisition of the forms learners are ready to acquire, thus aiding in the overall progress.

Additionally, if learners are incapable of acquiring any forms other than the ones that are next in their developmental sequence, any other forms taught in the classroom would be somewhat inconsequential. It follows, then, that classroom content should be based on these developmental patterns. Francis (2003) suggests that this level learner is allotting such a great deal of his or her attentional resources to meaning that copulas become practically nonessential for basic communication. A combination of clear grammatical explanations, abundant examples of the target forms in use plus explicit corrective feedback may speed the rate at which learners pass through these developmental stages.

\section{Conclusion}

The present study has investigated the acquisition of the principle Spanish copulas, ser and estar and has sought to identify stages through which learners pass, mastering each one before passing to the next. The nature of the copulas was considered and in light of previous research, the researcher determined that categorizing the uses of ser and estar by the communicative function of the speaker sheds more light on these developmental patterns. Based on the frequency of accurate responses in both a grammaticality judgment task and production, a modified list of the stages of development in the acquisition of these copulas was proposed.

It must be cautioned, however, that these results should be interpreted recognizing the limitations of the study. Most importantly, these data have not yet been statistically analyzed and therefore only suggest tendencies toward the interpretation offered here. Secondly, to gain a greater understanding of these stages, future studies should include learners from a variety of proficiency levels. This would allow greater generalizations to be drawn and may also provide data on the length of time learners pass at the different stages. Additionally, future studies may include the communicative functions which were not addressed here, 
namely the passive and instances in which adjectives may be paired with either copula, but with different interpretations.

\section{REFERENCES}

Bolinger, D. (1991). Essays on Spnaish: Words and Grammar. Newark, DE: Juan de la Cuesta. Bosque, I. (1992). "Verbos locativos en espanol. Aproximacion sintactico-semantica" en Romance Philology, 1992, 46, 2: 170-175.

Bull, W. E. (1965). Spanish for Teachers: Applied Linguistics. New York: The Ronald Press Company.

Butt, J. and C. Benjamin. (1994). A New Reference Grammar of Modern Spanish. Chicago: NTC Publishing Group.

Francis, S. (2003). Input Flooding and the Acquisition of the Spanish Verbs Ser and Estar for Beginning-Level Adult Learners. West Lafayette, IN: Purdue University Dissertation.

Geeslin, K. L. (2000). "A New Approach to the SLA of Copula Choice in Spanish" en Leow, R. y C. Sanz (eds.), Papers from the 1999 Conference on the Acquisition of Spanish and Portuguese. Somerville, MA: Cascadilla Press, 50-66.

Geeslin, K. L. (2002). "The Acquisition of Spanish Copula Choice" en Studies in Second Language Acquisition, 24: 419-450.

Gili Gaya, S. (1973). Vox Curso Superior de Sintaxis Española. Barcelona: Bibliograf.

Lema, J. (1995). "Distinguishing Copular and Aspectual Auxiliaries: Spanish Ser and Estar" en Amastae, J., Goodall, G., Montalbetti, M., \& M. Phinney, [eds] Contemporary Research in Romance Linguistics: Papers from the 22nd Linguistic Symposium on Romance Languages, Amsterdam, The Netherlands: John Benjamins Publishing Co., 257-274

Mesa Alonso, M, Domínguez Herrera, M., Pardon Sánchez, E. y N. Morales Aquilera. (1993). "Ser y estar: Consideraciones sobre su uso en español" en Islas, 104: 150-156.

Ramírez-Gelpi, A. (1995). The Acquisition of Ser and Estar Among Adult Native English Speakers Learning Spanish as a Second Language. Los Angeles, CA: University of Southern California Dissertation.

Silva-Corvalán, C. (1986). "Bilingualism and Change: The Extension of Estar in Los Angeles Spanish" en Language, 62: 587-608.

Stockwell, R. P., Bowen, J. D. y J. W. Martin (1965). The Sounds of English and Spanish. Chicago: The University of Chicago Press.

VanPatten, B. (1987). "Classroom Learners' Acquisition of Ser and Estar: Accounting for Developmental Patterns" en VanPatten, B., Dvorak, T. y J. F. Lee (eds) Foreign Language Learning: A Research Perspective, Cambridge: Newbury House, 61-75.

Whitley, M. S. (2002). Spanish/English Contrasts. Georgetown: Georgetown University Press. 